\title{
Sense Orientation
}

National Cancer Institute

\section{Source}

National Cancer Institute. Sense Orientation. NCI Thesaurus. Code C63550.

Having a DNA sequence identical to that of a messenger RNA molecule; the coding strand in double-stranded DNA. 